\title{
Exploring Prospective Structural Analysis to Assess the Relevance of Rural Territorial Development in Spain and Nicaragua
}

\author{
María del Mar Delgado-Serrano* \\ Mateo Ambrosio-Albalá ** \\ Francisco Amador *** \\ doi:10.III44/Javeriana.cdrı2-76.epsa \\ Recibido: 2014-12-20 Aprobado: 2015-04-27 Disponible en línea: 2015-10-0I
}

Cómo citar este artículo: Delgado-Serrano, M. del M., Ambrosio-Albalá, M., \& Amador, F. (2015). Exploring prospective structural analysis to assess the relevance of rural territorial development in Spain and Nicaragua.

Cuadernos de Desarrollo Rural, I2(76), 35-56. http://dx.doi.org/ı0.II144/Javeriana.cdrı2-76.epsa

* Profesora titular dpto. Economía, sociología y política agrarias universidad de Cordoba (España).

Correo electrónico: mmdelgado@uco.es

** Investigador asociado grupo de investigación SEJ-ıog. Universidad de Córdoba.

Correo electrónico : mateo.ambrosio@fastmail.fm

*** Universidad Loyola. Correo electrónico: famador@uloyola.es 


\begin{abstract}
Rural Territorial Development policy approach was launched in Europe to foster rural development under the LEADER initiative. It sparked off great interest in Latin America. We analyse the role played by RTD principles in the dynamics and evolution of four rural areas in Spain and Nicaragua. In doing so, we provide empirical understanding on the validity of the principles to boost rural change and contribute to evidencebased policy-making. Methodologically, we explore the use of participatory prospective tools that apprehend rural areas' evolving and complex nature. The potential of Prospective Structural Analysis to describe rural dynamics, and to support social changes and decision-making is tested.
\end{abstract}

Keywords:

evidence-based policy-making; regional planning; Europe; Latin America

\title{
Exploración del Análisis Estructural Prospectivo para Evaluar la Importancia del Desarrollo Rural Territorial en España y Nicaragua
}

\section{Resumen}

La estrategia de las políticas de Desarrollo Rural Territorial se lanzó en Europa con el fin de estimular el desarrollo rural en el marco de la iniciativa LEADER, la cual generó gran interés en América Latina. Esta investigación analiza el rol que los principios del DRT en las dinámicas y evolución de cuatro áreas rurales en España y Nicaragua. En desarrollo de dicho análisis nos es posible llegar a un entendimiento empírico de la validez de los principios para el estímulo del cambio rural y la contribución a la elaboración de políticas basadas en evidencias. En la metodología exploramos el uso de herramientas prospectivas participativas que comprenden la naturaleza compleja y en evolución de las áreas rurales. Se pone a prueba el potencial del Análisis Estructural Prospectivo para la descripción de las dinámicas rurales y dar soporte a los cambios sociales y la toma de decisiones.

\section{Palabras Clave:}

elaboración de políticas con base en evidencias; planeación regional; Europa; América Latina 


\title{
Exploration de l'analyse structurale prospective pour évaluer l'importance du développement rural territorial en Espagne et Nicaragua
}

\author{
Résumé \\ La stratégie des politiques du Développement Rural Territorial s’est lancée avec l'objectif de stimuler \\ le développement rural dans le cadre de l'initiative LEADER, laquelle a produit un grand intérêt en \\ Amérique Latine. Cette recherche analyse le rôle que les principes du DTR dans les dynamiques et \\ évolution de quatre zones rurales en Espagne et Nicaragua. En déroulement de cette analyse il est possible \\ d'arriver à une compréhension empirique de la validité des principes pour la stimulation du changement \\ rural et la contribution pour l'élaboration de politiques fondées sur les évidences. Dans la méthodologie on \\ a exploré l'usage d'outils prospectifs participatifs qui englobent la nature complexe et en évolution des zones \\ rurales. On preuve la puissance de l'analyse Structurale Prospective pour le description des dynamiques \\ rurales et donner support aux changements sociales et la prise de décisions.
}

Mots clés:

élaboration de politiques avec une base sur les évidences; dessin régional; Europe; Amérique Latine

\section{Explorando a análise prospetiva estrutural para avaliar relevância do Desenvolvimento Rural Territorial na Espanha e na Nicarágua}

\author{
Resumo \\ A abordagem da política de Desenvolvimento Rural Territorial foi lançada na Europa para promover o \\ desenvolvimento rural no âmbito da iniciativa LEADER. Ela desencadeou grande interesse na América \\ Latina. Analisamos o papel desempenhado pelos princípios de DRT na dinâmica e evolução das quatro \\ áreas rurais na Espanha e Nicarágua. Ao fazê-lo, fornecemos compreensão empírica sobre a validade \\ dos princípios para impulsionar a mudança rural e contribuir para a formulação de políticas baseadas \\ em evidências. Metodologicamente, exploramos o uso de ferramentas de prospectiva participativa que \\ compreende áreas rurais em evolução e a natureza complexa. O potencial da Analise Prospectiva Estrutural \\ para descrever dinâmicas rurais e apoiar mudanças sociais e de tomada de decisões foi testada.
}

Palavras-chave:

formulação de políticas baseadas em evidencias; planejamento regional; Europa; América Latina 


\section{Introduction}

National and international economic policies have succeeded in promoting economic growth over the last decades (Commission on Growth and Development, 2008; World Bank, 2008a; Battaglia et al., 20II). Yet important spatial balances remain unsolved. Equity and fair growth distribution is a pending issue and development remains elusive for many regions, mainly rural areas (Kay, 2009).

Spatial inequalities and different development pathways have been traditionally of interest for the economic science. Development economists have long tried to improve the understanding on how economies set in a path of wealth creation and progress, while others get stuck in 'poverty traps'.

Policy approaches effective at reducing the gaps between best performing and lagging regions are still missing. Rural areas worldwide often fall under the lagging regions category. Fighting rural poverty in developing countries and enhancing territorial cohesion in the developed ones explain rural development (RD) as a priority in public policies (OECD, 2006; EC, 20II; Esparcia and Escribano, 20I2). Yet generalizations may overshadow the heterogeneous landscape of rural areas and of their potentialities (Commins, 2004; IFAD, 2010).

Driven by a strong public support, approaches to $\mathrm{RD}$ policies have proliferated in the last decades. To recognize the multiple dimensions involved in the development of rural areas, rural studies have embraced contributions from a wide array of disciplines (sociology, politics, anthropology, ecology, or history). The complexity of rural areas, the impacts and changes they face, the importance of context-specific factors, and the role of local actors and institutions are gaining relevance in RD research and policy agenda.

The European Union (EU) have long acknowledged and supported the key role of the rural areas and their assets in enhancing territorial cohesion, generating growth, and sustaining the welfare state across Europe (EC, 1999; EC, 2006; Committee of the Regions, 20I3). Rural territorial development (RTD) is a place-based policy approach targeting rural areas.

RTD does not envisage rural territories as a mere set of resources or as a physical support for resources and human activities. Every single resource, asset, and agent can potentially trigger or hinder structural changes. As a social construction, the territory itself becomes a 'living actor' shaped and driven by the aggregate decisions, knowledge, and perceptions of local actors. Territorial change dynamics come out from the complex interaction of multiple internal factors, but also external forces, like globalisation and markets. 
The LEADER Initiative set out the approach foundations in the EU. Started as a pilot initiative, it proposed a policy approach based on bottom-up and territorial approaches. The following editions shaped and refined the approach, that later became mainstreamed within the EU RD policy (EC, 2005). Furthermore, the European Economic and Social Committee recommended using it in urban areas for implementing development and investment strategies (EESC, 20II).

LEADER and RTD policy approaches also sparked off great interest in Latin America. Some initiatives across the subcontinent are: the Central AmericanStrategy for Rural Development (ECADERT) of the Central American Integration System (SICA) (2010), the Law № 18.126 of Decentralization of Uruguay (2007), the definition of Territories of Citizenship and Territories of Identity (2008) by the Government of Brazil, and the project Models on Territorial Approach to Rural Development of the Andean Community (2009). The mixed results and progress of these initiatives to date prompted a reflection on the role and applicability of the LEADER principles to non-EU contexts.

The study was defined with a double objective: I) to assess how local actors perceive the role played by RTD principles in the development dynamics of rural areas; and 2) to explore the use of participatory prospective tools to describe the dynamic and complex nature of rural development. The research team applied the Prospective Structural Analysis (PSA) tool from 'la prospective' (strategic foresight) kit (Godet, 1986) and tested its performance to understand rural dynamics in two Spanish and two Nicaraguan case studies (CS).

The PSA was selected since it i) identifies the elements driving changes in a system; ii) deals with multiple variables; iii) locates the interrelationships among variables, including the hidden ones; and iv) shows the system trends and changes through time (Godet, 1986). Finally, it is a participatory technique that draws the vision of local actors about their territory through a socially-organized learning process (Gertler and Wolfe, 2004).

The paper explores the potential of the RTD approach as a theoretical and policy framework for rural areas with uneven development levels, and of the PSA as a participatory tool to support decision-making processes. Both objectives are innovative. No similar study has been found in the literature combining both theoretical and methodological approaches in rural areas.

Section 2 overviews the RTD approach, followed by a brief description of the PSA in section 3, and of the empirical application in section 4 . Section 5 includes the result discussion and section 6 draws the main conclusions. 


\section{Changes in rural development thinking. The emergence of rural territorial development}

Over the last decades, rural studies and RD policies have gone through some fundamental changes (Ellis and Biggs, 200I; Irwin et al., 2010). Past RD programs featured non-coordinated, sector-based, horizontal, and top-down policies and strategies. Well-established and macro-level economic theories (neo-classical equilibrium theories, disequilibrium theories, Marxian and political economy approaches, human development economics, institutional economics...) provided the entry points for earlier approaches to RD policies. Poor results paved the way for new approaches that emphasized coordination, multi-sector integration, context-specificity, sustainability, and bottom-up strategies (LEADER European Observatory, 1999; OECD, 2006). These new approaches mostly rely on a 'learning by doing' practice and are considered as empirically grounded theory (Van der Ploeg et al., 2000).

RTD emerged as a policy adaptation of the regional economy, local development, and bottom-up approaches to the dynamics and problems of the late 80's rural Europe (Pike et al., 2006). It aggregates contributions from different theoretical frameworks to encourage RD through territory-based interventions. The LEADER European Observatory (1999) proposed 7 principles to define RTD: I) area-based; 2) bottom-up; 3 ) public-private partnerships; 4) innovative character of actions; 5 ) linkages and multisectoral character of actions; 6) networking and transnational cooperation; and 7) local ownership in the methods of management and financing. The authors propose two additional principles, for more responsive and effective rural policies: 8) result-oriented actions; and 9) coordination of local strategies and national policies (cross-scaling).

Rural change is an extremely complex and nuanced phenomenon. The theoretical underpinnings of RTD builds upon the analysis of rural change, using evidence and case studies as the unit of analysis. The study of the LEADER program and its impact in the EU rural areas (Saraceno, 1994; Van der Ploeg and Long, 1994; Marsden, 1995; Ray, 1997; Bryden, 2003) laid the ground of the approach. Other researchers have highlighted the successes and failures of RTD strategies in rural areas. Pike et al. (2006) and Camagni (2008) deepen the essential role of local, endogenous, and territorial assets. Shortall (2008) analysed the difficulties in establishing locally-embedded partnerships and social inclusion. High and Nemes (2007) presented the differences between traditional government approaches and new governance systems and the relevance of a new institutional architecture. Bosworth and Willet (20II) explored the role of innovation capacities and newcomers in the development dynamics. Shucksmith (2010) analysed the role of neo-endogenous development and Tovey (2008) the role 
of RD in the knowledge society. Halseth et al. (2009) highlighted the influence of globalization and the global economy in rural areas.

In LatinAmerica, Sepúlveda et al. (2003), Schetjman and Berdegué (2004), and Bebbington et al. (2008) developed the approach based on the analysis of Latin American rural territories. More recently, RIMISP conducted one of the benchmark studies in the region through the 'Rural Territorial Dynamics' research project, based on the study of 25 territories in II Latin American countries.

RTD understands development as the combination and interactions of many factors affecting economic, institutional, and cross-cutting processes. Defining elements of the RTD are: devolution of decision-making power, context-specific approaches, area-based partnership, revalorisation of endogenous assets, territorial competitiveness, as well as stakeholder participation and co-ordination among sectors, agents and administrations (Pérez-Correa and Sumpsi, 2002; Sepúlveda et al., 2003; Delgado-Serrano et al., 2004; Schejtman and Berdegué, 2004; Ambrosio-Albala, 2007; Bebbington et al., 2008).

Under the RTD perspective, local capacities are essential to transform local assets and be innovative, as well as to interact and influence factors, networks, and agents external to the territories. Rural territories turn into social constructions shaped by the actors, resources, and processes resulting from their interactions and conflicts (Boisier, 2003; Bebbington et al., 2008). The engagement and participation of local actors, as well as a larger responsibility of public administrations (from local to higher levels), are critical for opening social, institutional, and economic cooperation paths and setting up functional governance mechanisms (Capriati, 200I). Finally, local involvement and state policies acting together are necessary to drive good results in RD.

\section{Prospective structural analysis: a tool to assess complex realities}

Foresight analysis aims to explore feasible futures in the context of social sciences (Coates et al., 2010). Based on the current state of a given system, the analysis elaborates on economic, social, scientific, and technological factors to envisage potential future states. It helps describe present situations and draw future scenarios. These techniques assume that the future is different from the past and is not imposed, but can be built (Berger, 1964).

Initial strategic foresight analysis turned from a philosophical and literary form to be operationalised through a variety of quantitative methods, which together make up a toolbox for the implementation of the method (Gómez-Limón et al., 2009). The PSA 
is part of this toolbox and a step in the process of scenario building. It helps identify the most influential variables and those most sensitive to be influenced in a system. The technique relies upon a process of deliberations, carried out through participatory workshops, where stakeholders agree on the main variables shaping the evolution of a system and their mutual influences.

\section{Phases of Prospective Structural Analysis}

PSA is structured in three phases (see Godet, 1986; Ambrosio-Albala, 2007; and Delgado-Serrano et al., 20I4, for details). The first two are developed through workshops and the third one using MICMAC software.

\section{Phase I. List of variables}

To define the system and its external environment, the participants agree on a comprehensive list of variables. Additional interviews with experts or stakeholders can be useful to complete and further refine the list, which should not exceed 70-80 variables. Every variable must be clearly defined, characterised, and understood by all the participants.

\section{Phase 2. Description of the relationships between variables}

In this phase, the workshop participants discuss on how the variables mutually interact. Instead of cause-effect relationships, the discussion addresses relationships of influence. To quantify the strength of the influence, the participants agree on a value, factoring the sign of the influence out. The intensity of influences ranges from 0 (no influence) to 3 (strong influence). A P-value can also be assigned when the influence is likely to happen in the future. The assessment uses a cross-impact matrix where each element $\left(\mathrm{a}_{\mathrm{ij}}\right)$ represents the influence of a variable in row (i) over a variable in column (j). The discussions about the type and character of the influences should be recorded in order to help interpreting the results. The final outcome is the matrixof direct influences (MDI). Filling out the matrix requires an in-depth reflection and discussion about the nature of the influences. Therefore the views of the participants strongly determine the final outcome.

\section{Phase 3. Analysis of variables}

This phase identifies the key variables using a matrix calculation method called MICMAC. MDI gathers first order influences between variables. The direct influence of any given variable $k$ is the sum of the values of row $k$ in the MDI, as is 
the direct dependence of variable $k$ the sum of the values in column $k$. The pair of values is referred to as proportions.

However, the significance of a variable for the system does not only depend on its direct influences, but also on the sheer amount of indirect relations. Based on the properties of the Markov chains and the Boolean matrices, MICMAC calculates successive matrices rising to second, third, ...n powers, to consider influences of higher order. From a given power ahead, the ranking of proportions remains constant (Godet, 200I). That 'stable' final matrix is called the Matrix ofIndirect Influences (MII). MII shows the role of the variables in the medium and longterm, since indirect influences take time to occur.

MICMAC uses hierarchies and charts to display the variables, like the influencedependence map. Depending on the sort of influences plotted (direct or indirect), the map shows the explicit or hidden role of the variables, highlighting possible changes in time. The maps show how stakeholders perceive the system and what they consider to be constraints, opportunities, and potentialities for change. The technique clusters the variables into categories, where each category refers to a different function in the system dynamics.

This research analysed the clusters combining two logics: the input-output logic (Godet, 1986) and the strategic logic (Astigarraga, 2006). According to the former, the input variables condition the evolution of the system and the output show the direction of the changes. The latter plots the variables along the strategic diagonal and allocates a certain degree of leverage depending on the distance to the origin. The larger the distance, the higher the leverage or multiplier effect and the more strategic the element is for the system. In turn, the more strategic a variable is, the more receptive to influences from other variables, and thus the less stable the variable becomes. Five clusters are identified combining both logics (Figure I).

Input variables are highly influential and also independent. They describe the system and condition any changes. Output variables explain the impacts resulting from other variables, mainly input and regulator. Regulator variables can leverage influences across the system, as they both receive and exert influences. Stake variables are highly influential and highly dependent, and thus unstable (actions taken on them cascade through others affecting the system dynamic). Input and stake variables should be carefully analysed when planning. Autonomous variables are neither influential nor dependent. They often describe inertial or prevailing trends that change little over time. 


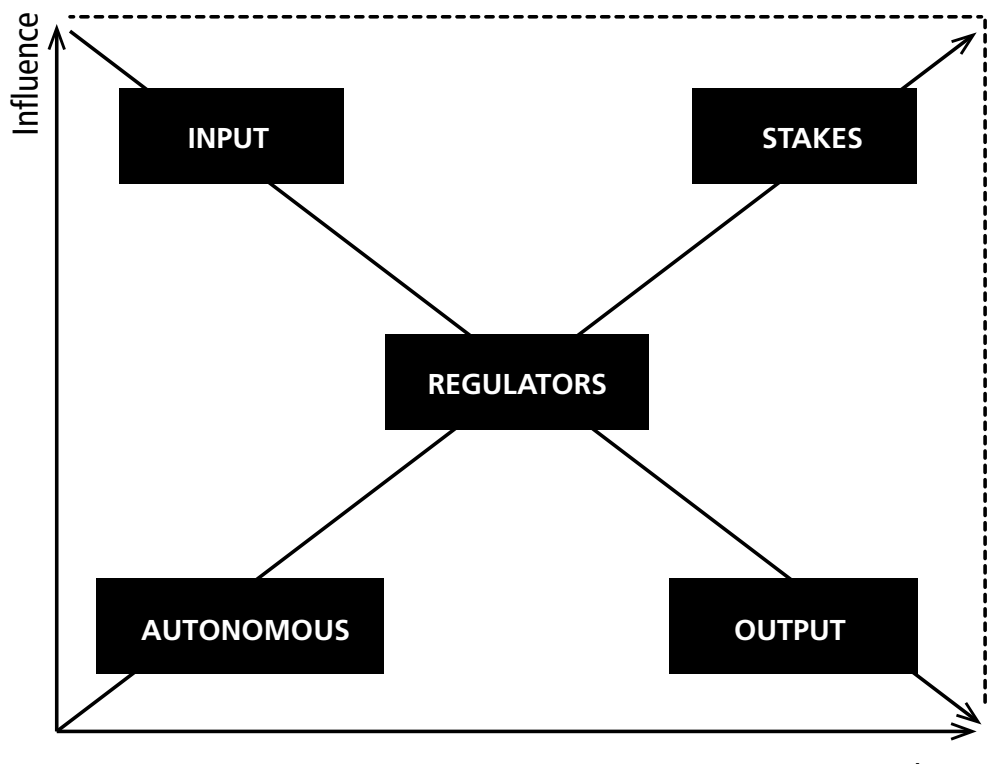

Strategic diagonal

Dependence

Figure i. Clusters according to the input-output and strategic logics

Source: Own elaboration based on Godet (200I) and Astigarraga (2006)

The comparison between the direct and indirect classifications of any given variable reveals its role within the system, currently and in the longer term, respectively.

PSA's added value for planning and policy-making in rural territories Rural territories are complex decision-making environments, where a multitude of stakeholders with multiple and often conflicting objectives interact. Rural change results from the mutual interaction of many factors, internal and external to the system. PSA helps analyse how those factors interact with each other, and how changes in those interplays impact throughout the system. It is based on qualitative considerations about the nature of interrelations and not on hard evidence, enabling comparative analysis with contexts that often lack reliable statistics.

The MICMAC software allows clustering and creating hierarchies of factors according to how local stakeholders perceive the mutual influences among the elements 
of a system. This feature can be of high interest for policy-making, since often policies are focused on variables not relevant for local actors, leading to policy failures.

The hierarchies and graphs based on indirect influences also show the system future trends. The importance of a variable does not only stem from its direct relations with other variables (stated by the participants, like in other strategic or spatial planning techniques such as Delphi analysis, panel of experts, etc.), but from the web of indirect interrelationships revealed by the MII (Godet, 1994).

Finally, the method stimulates and structures a collective reflection process about the future and highlights the necessary actions to reach it (Godet, 200I; Gavigan and Scapolo, 200I). It helps shaping rural territories as social constructions, where the interpretations of local agents on constraints, potentialities, and incentives for change are fundamental. Participation of local people in the process and ownership of results are crucial to boost change and orientate territorial planning strategies.

PSA has been used in several experiences at regional level (Kelly, 2004; Reutter, 2006; Gómez-Limón et al., 2009). Ambrosio-Albalá et al. (20II) and Perez-Hernandez et al. (2014) describe applications of the PSA as a tool for strategic rural planning in Andalucía (Spain). No work has been found in the literature using PSA as a tool to analyse the role played by the RTD principles in the development dynamics of rural territories as proposed in this paper.

\section{Assessing development dynamics in the territories}

\section{Case Studies}

PSA has been applied in four rural areas: Pedroches and Guadiato in Spain, and Camoapa and Matiguás in Nicaragua. The selection criteria ultimately aimed to serve the research objective of validating the RTD approach principles and the role of the variables in different contexts. Spain and Nicaragua have uneven development levels; therefore the influence of general context factors can be tested. The CS within each country are unevenly developed contiguous territories to avoid geographical biases and to consider the influence of context-specific factors (Table I). In all CS, exogenous policies or incentives for RD were already in place and endogenous development processes have emerged in the last 10-15 years. 


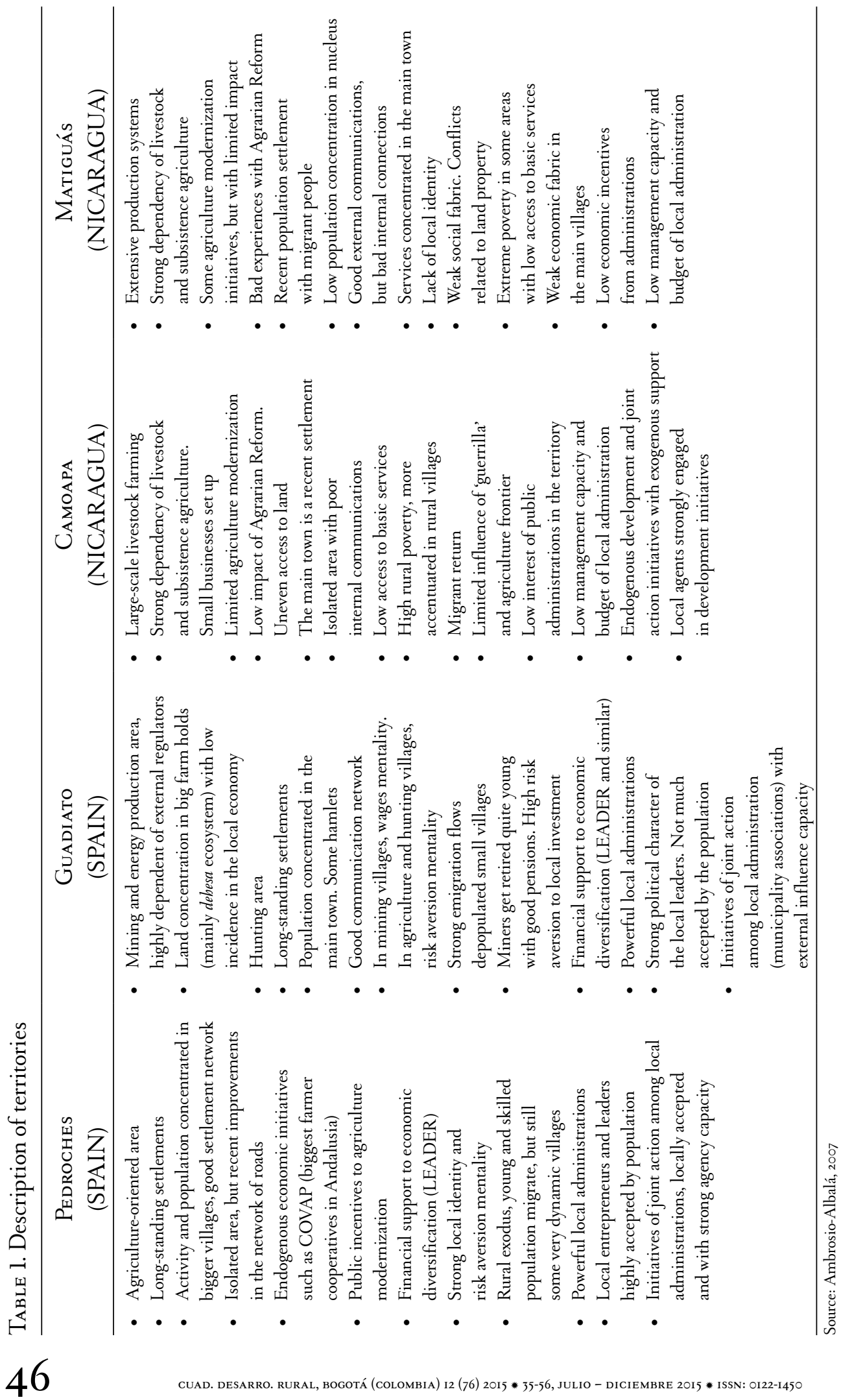




\section{PSA application}

For this study, the team slightly adapted the method. A first-cut of the variable list defining RTD principles followed a literature review. The list was refined through interviews and discussions with academics and practitioners. The draftlist was validated through consultations and interviews with 29 experts and stakeholders from both countries to offer a comprehensible list in all the areas. Experts and stakeholders were selected based on: the role played or membership in territory and community-based organizations and associations; time living in the area; active engagement in past and/or on-going development initiatives and projects; and perceived recognition as key actors in the territory. This adaptation aimed to ensure that the variables were consistent with the RTD principles and meaningful to capture the dynamics in every CS. To come up with one single and consolidated list of variables, the refinement process required two iterations with the local stakeholders. Table 2 shows the variables associated to these principles.

TABLE 2. Variables defining the different RTD principles

\begin{tabular}{lll}
\hline \multicolumn{1}{c}{ PRINCIPLES } & \multicolumn{1}{c}{ VARIABLES } & \multicolumn{1}{c}{ ID } \\
\hline \multirow{2}{*}{ Area-based } & Natural Resources & RecNatur \\
& Local identity & Ident \\
& Settlement patterns & Asenta \\
& Land tenure patterns & Tierra \\
\hline \multirow{2}{*}{ Bottom-up } & Collective development actions & Sociab \\
& Political representativeness & Repres \\
\hline \multirow{4}{*}{ Public-private partnership } & Local leadership & Lider \\
& Joint actions among public and business actors & AC_GobPriv \\
& Joint actions among public actors and civil society & AC_GobSoc \\
& Joint action between business actors and civil society & AC_PrivSoc \\
& Joint action among local governments & AC_GobLoc \\
\hline \multirow{2}{*}{ Innovation } & Modernization of agriculture production systems & Modern \\
& Access to information and mass media & Media \\
\hline \multirow{3}{*}{ Multi-sector } & Influence of external agents & Extern \\
\hline Networking and & Diversification of household incomes and activities & Divers \\
transnational cooperation & Access to basic public services & Servic \\
\hline \multirow{2}{*}{ Management and financing } & Joint action among business actors & Infraest \\
\hline \multirow{2}{*}{ Result-oriented actions } & Cocal government & OrgProfes \\
\hline Coordination of policies & Rural poverty & AC_Priv \\
\hline and strategies & Migration strategies & GobLoc \\
\hline & Administrative organization & Capit \\
\hline
\end{tabular}

Source: own elaboration 
The local experts and stakeholders described the relationships among the variables in the list, filling out the MDI. The influences were analysed and their intensity $(0, \mathrm{I}$, 2, 3, or P) agreed upon by consensus.

In phase 3, MICMAC software was used to obtain the MII, to draw the direct and indirect influence-dependence maps (DIDM, IIDM), and to classify the variables in clusters. These outcomes were thenvalidated with the participants and the counterintuitive results were further discussed and analysed.

TABLE 3. Classification of the variables according to the Direct and Indirect Influence Maps

\begin{tabular}{|c|c|c|c|c|c|c|c|c|c|}
\hline \multirow[b]{2}{*}{ PRINCIPLES } & \multirow[b]{2}{*}{ ID } & \multicolumn{4}{|c|}{ Direct INFLUENCES } & \multicolumn{4}{|c|}{ INDIRECT INFLUENCES } \\
\hline & & I & $\mathrm{T}$ & $\mathrm{O}$ & A & I & $\mathrm{T}$ & $\mathrm{O}$ & A \\
\hline \multirow{4}{*}{ Area-based } & RecNatur & & 3 & I & & & 2 & I & I \\
\hline & Ident & I & 3 & & & I & 3 & & \\
\hline & Asenta & 3 & I & & & 2 & 2 & & \\
\hline & Tierra & I & 3 & & & I & 3 & & \\
\hline \multirow{2}{*}{ Bottom-up } & Sociab & & 2 & I & I & & 3 & I & \\
\hline & Repres & & 2 & I & I & & 2 & I & $\mathrm{I}$ \\
\hline \multirow{5}{*}{ Public-private partnership } & Lider & & I & & 3 & I & 2 & & I \\
\hline & AC_GobPriv & & & I & 3 & & & I & 3 \\
\hline & AC_GobSoc & & I & I & 2 & & 2 & $\mathrm{I}$ & $\mathrm{I}$ \\
\hline & AC_PrivSoc & & & & 4 & & & & 4 \\
\hline & AC_Gob & & I & I & 2 & & 3 & & I \\
\hline \multirow{3}{*}{ Innovation } & Modern & & 2 & I & I & & 3 & & I \\
\hline & Media & $\mathrm{I}$ & I & & 2 & I & 3 & & \\
\hline & Extern & & 2 & 2 & & & 2 & 2 & \\
\hline \multirow{3}{*}{ Multi-sector } & Divers & & 2 & I & I & & 2 & $\mathrm{I}$ & I \\
\hline & Servic & $\mathrm{I}$ & I & $\mathrm{I}$ & $\mathrm{I}$ & I & $\mathrm{I}$ & I & $\mathrm{I}$ \\
\hline & Infraest & 2 & 2 & & & 2 & 2 & & \\
\hline \multirow{2}{*}{ Networking and transnational cooperation } & OrgProfes & & & & 4 & & & & 4 \\
\hline & AC_Priv & & & I & 3 & & & I & 3 \\
\hline \multirow{2}{*}{ Management and financing } & GobLoc & I & 3 & & & & 4 & & \\
\hline & Capit & I & 2 & & I & & 4 & & \\
\hline \multirow[t]{2}{*}{ Result-oriented actions } & Pobrez & & 2 & 2 & & & 2 & 2 & \\
\hline & Emigr & I & 2 & & I & I & 2 & & I \\
\hline Coordination of policies and strategies & Adminis & $\mathrm{I}$ & 2 & & I & 2 & 2 & & \\
\hline
\end{tabular}

I: Input; T: Transmission; O: Outcomes; A: Autonomous

Source: own elaboration based on data from Ambrosio-Albalá, 2007. 


\section{Discussion}

Table 3 compares the role of the variables in the four CS using the direct and indirect influences. To simplify, only four categories have been used: input, output, transmission (including regulator and stake variables), and autonomous variables. The figures refer the number of territories where a given variable falls into the same category. The variables with values equal to ' 3 ' or ' 4 ' play the same role in at least one territory of each country. The variables with values equal to ' 2 ' were also considered.

\section{Analysis of the Direct Influence-Dependence Map}

DIDM shows the role that the variables currently play. The variables included in the area-based principle act as transmission or input. Stakeholders perceived them as having the capacity to stir changes in the territories.

The variables in the bottom-up principle act as transmission in two cases. However, both variables are autonomous in the most developed territory (Pedroches in Spain) and output in Camoapa (Nicaragua).

The variables under the public-private partnership principle are largely perceived as autonomous and with little capacity to prompt changes. Only some of these variables classify as transmission in the Nicaraguan CS.

The variables under the innovation principle display a broader range of roles. The modernization of agriculture acts as transmission in the Nicaraguan CS, while in the Spanish CS its role is seemingly irrelevant. The access to information and mass media is autonomous in the two Spanish CS, but has a higher influence capacity in the Nicaraguan CS. Finally, the influence of external agents is a transmission variable in the Spanish CS, but an output variable in the Nicaraguan CS.

The variables defining the multi-sectoral character of actions principle show different roles. The access to infrastructures shows strong influence in the four CS, either as an input in the better-off areas or as a transmission in the underperforming ones. The bousehold income and activity diversification act as a transmission variable in the two Nicaraguan CS and plays a limited role in the Spanish CS. Access to public services play a different role in every territory.

Stakeholders did not perceive Networking and transnational cooperation variables as having any relevant influence in their territories.

Methods of management and financing variables act as input or transmission. Only in Matiguás access to finance shows up as an autonomous variable, reportedly as a consequence of the poor access to credit for producers in the area. 
In the result-oriented actions principle, the rural poverty alleviation strategies act as transmission in the Nicaraguan CS and as output in the Spanish CS, in accordance with the development disparities between the two countries. Migration strategies act as input or transmission in three CS and as autonomous in the least developed one.

Finally, the variable defining the coordination of public strategies at local and higher levels acts as transmission in ${ }_{3} \mathrm{CS}$, but is autonomous in the most developed one, Pedroches.

\section{The hidden influences: Shifts between the Direct and the Indirect Influence-Dependence Maps}

The shifts in the role played by the variables between the DIDM and IIDM show the changes that can happen over time. Once factored the indirect influences in, the picture described in the previous section remains largely unaltered. However a remarkable number of variables previously classified as autonomous moved up along the strategic diagonal to become transmission variables. That change is due to the effect of their indirect influences, whose aggregate impact takes time to unfold. The direct influences of those variables showed to a limited extent their full transformative potential for the system.

There are few changes in the role played by the variables included in the area-based principle. Bottom-up variables become slightly more influential. Severalpublic-private partnership variables change their role: local leadership, public sector-civil society joint actions, and joint actions among local governments, shift from autonomous to transmission or input, increasingtheir influence capacity with time.

Innovation variables also increase influence capacity in the longer term, acting as transmission or input. Only in Guadiato the modernization of agriculture is considered as autonomous. In that Spanish region, the long-standing mining sector has strongly discouraged any entrepreneurial attitudes. The access to information acts as input or transmission in all the four cases.

Methods of management and financing variables increase their influential capacity, acting as transmission variables in all the cases. Consequently, they are perceived as leverage factors.

Coordination of strategies at local and national levels variables increasetheir influence capacity acting as transmission in the less developed areas and as input in the better-off ones.

A more detailed analysis shows three patterns in the evolution of variable clustering. The variables included in the area-based principle, the local ownership of the 
methods of management and financing, and the coordination of local strategies and national policies act as input or transmission in both maps, gaining relevance for the system as transmission variables within the IIDM. Participants perceive the principles linked to endogenous and physical resources, and local agency as key factors for development and change, as expected by the RTD approach. Asinput or transmission variables, any influence exerted on them will be further transmitted to impact other elements in the system and bring about changes.

The variables defining the bottom-upapproach, the public-private partnerships and the innovation principles present differences in DIDM, but consolidate their transmission role in IIDM. These principles linked to intangibles increase their role as drivers in the long term. They are the results of other variables that influence them, thus they need more time and effort to influence. The findings also confirm the expected role in RTD.

The variables in the multi-sectorial character of actions, the result-oriented actions, and the networking principles do not change and show a higher dispersion of roles.

\section{Conclusions}

Public policies increasingly advocate for context-specific approaches and move away from any kind of one-size-fits-all response. This article provides evidence that local actors from rural areas with different development settings perceive a set of common factors driving change in their territories. The RTD encompasses those common factors under their defining principles. The conclusions are organized around the two objectives of the paper.

\section{On the role of the RTD principles to promote rural change}

The first outcome of comparing RTD principles in rural areas of Europe and Latin America is that the stakeholders identified most of them as relevant factors for development. Regardless of the development settings, participants perceived that RTD principles play a similar role in explaining the changes in their territories. The coincidences mostly refer to factors with capacity to leverage influences in their systems, namely, to be influenced and to influence other factors in the territories.

Similar backgrounds and settings might as well explain coincidences between neighbouring territories. Yet, coincidences between non-neighbouring territories suggest similar patterns in the perception of the actors, without consideration of their 
development settings. Moreover, these coincidences suggest that the RTD principles offer an appropriate lens to realize those patterns as well as the drivers of change. This evidence supports the use of RTD principles as a basis for RD policy-making in different contexts.

The high number of variables interacting in the development processes and playing an important role shows the complexity of RTDand the importance of using integrated approaches, and not simple and mono-dimensional analysis. Flexible and adaptive policies, and continuous monitoring and evaluation processes providing feedback and driving decision-making are needed.

\section{On the use of the PSA to assess rural dynamics}

The PSA helps detect patterns and relationships in subjective data, which might otherwise not be apparent. Furthermore, it narrows down a complex set of data and offers outputs that are more readily interpreted, and can be used for efficient and effective policy-making. The outcomes rank the system elements providing the decision-making process with the priorities of the actors.

Effective RTD needs collective action and a shared vision for the common future. PSA is useful to structure discussions around the dynamics of a system and makes easier to come up with that shared vision through a reflexive process. DIDM and IIDM classifications shed light on the role played by each variable in the short and medium/long term, highlighting the variables that can stir changes and those with limited influence capacity to do so, according to the views of the actors.

The tool provides valuable bottom-up knowledge to policy-makers and local stakeholders to prioritize investments and to trigger changes. Given the limited funds available in rural areas, the pressures to make decisions without analysing different alternatives, and the limited knowledge of the impacts derived from decision-making, the technique can be very useful, especially when combined with other quantitative and objective techniques.

Subjectivity has a fundamental role, since the definition of the variables and the influence relations are based on the opinion of the participants. Far from being considered a limitation, it offers a stimulating potential to validate rural singularities. As RTD advocates, rural change relies on the perceptions and attitudes of local actors, which necessarily have to be taken into account in any future change.

Properly applied, the tool can be time-consuming and requires a considerable involvement and reflection from local key actors. 


\section{References}

Ambrosio-Albalá, M. (2007). Elementos institucionales en las zonas rurales: Una propuesta metodológica para su identificación y valoración en comarcas de Andalucía y Nicaragua (Doctoral dissertation). University of Córdoba, Spain.

Ambrosio-Albalá, M., Martín-Lozano, J. M., \& Pérez-Hernández, P. P. (20II). Aplicación del análisis estructural de prospectiva al diseño de estrategias de desarrollo rural: el caso de la comarca de Jerez. Estudios de Economía Aplicada, 29(I), 247-278.

Astigarraga, E. (2006). Mic-Mac: analisis estructural en prospectiva. Retrieved from http://www.prospectiva.eu/blog/210

Battaglia, L., Bellú, G. L., Dieng, C., \& Tedesco, I. (20II). Development paradigms and related policies. Retrieved from http://www.fao.org/fileadmin/user_upload/tcas/ projects/dev_paradigms_LiteratureReview2orı.pdf

Bebbington, A., Abramovay, R., \& Chiriboga, M. (2008). Social movements and the dynamics of rural territorial development in Latin America. World Development, 36(12), 2874-2887.

Boisier, S. (2003). ¿Y si el desarrollo fuese una emergencia sistémica? Revista Reforma $y$ Democracia, 27. Retrieved from http://www.clad.org.ve/indices27.html

Bosworth, G., \& Willett, J. (20II). Embeddedness or escapism? Rural perceptions and economic development in Cornwall and Northumberland. Sociologia Ruralis, $5 I$, I95-2I4.

Bryden, J. (2003). Changes in European Rural Areas. Proceedings of the International Rural network Conference 'Taking Charge'. Inverness June. [Ed. N. Swan]. The International Rural Network.

Camagni, R. (2008). Regional competitiveness: towards a concept of territorial capital. In R. Capello, R. P. Camagni, B. Chizzolini, \& U. Fratesi (Eds.), Modelling regional scenarios for the enlarged Europe (pp. 33-47). Springer, Berlin Heidelberg.

Capriati, M. (200I).The merits and challenges of the Deployment of Foresight Methods in Less-Developed Regions. IPTS Report 59. Retrieved from http://www.jrc.es/home/ report/spanish/articles/vol $59 / \mathrm{FR}_{4} \mathrm{~S}_{596}$.htm

Coates, J., Durance, P., \& Godet, M. (2010). Strategic foresight issue: introduction. Technological Forecasting and Social Change, $77(9)$, I423-I425.

Commins, P. (2004). Poverty and social exclusion in rural areas: characteristics, processes and research issues. Sociologia Ruralis, 44(I), 60-75. 
Commission on Growth and Development (2008). The Growth Report. Strategies for sustained growth and inclusive development. Washington: The World Bank Group.

Committee of the Regions (2013). Opinion of the Committee of the Regions on 'The sustainability of rural areas', OJEC 2013/C 356/14.

Delgado-Serrano, M. M., Ramos, E., \& Cañizares, E. (2004). New Institutions in European Rural Development Programmes: Between the top-down and the bottom-up approach. The case of Andalusia (Southern Spain), In G. Van Huylenbroeck, W. Verbeke, L. Lauwers (Eds.), Role of Institutions in Rural Policies and Agricultural Markets. Elsevier, Amsterdam.

Ellis, F., \& Biggs, S. (200I). Evolving Themes in Rural Development I950s-2000s. Development Policy Review, 19 (4), 437-448.

Esparcia, J., \& Escribano, J. (20I2). La dimensión territorial en la programación comunitaria y el nuevo marco de políticas públicas: desarrollo rural territorial, reforma de la PAC y nuevo LEADER. Anales de Geografía, 3(2), 227-252.

European Comission (1999). European Spatial Development Perspective. Towards balanced and sustainable development of the territory of the European Union. European Commission, Luxemburg.

European Comission (2005). Council Regulation (EC) No 1698/2005 of 20 September 2005 on support for rural development by the European Agricultural Fund for Rural Development (EAFRD). OJEC 2005 L 277000 - 0040.

European Comission (2006). Council Decision of 6 October 2006 on Community strategic guidelines on cohesion. 2006/703/EC.

European Comission (20II). Territorial Agenda of the European Union 2020. Towards an Inclusive, Smart and Sustainable Europe of Diverse Regions. Agreed at the Informal Ministerial Meeting of Ministers responsible for Spatial Planning and Territorial Development on igth May 20II GödöllD, Hungary.

European Economic and Social Committee (20II). Opinion of the EESC on “LEADER as a tool for local development”.OJEC $201 \mathrm{C}$ C 376 0015-00I8.

Gavigan, J. P., \& Scapolo, F. (200I). Regional Foresight - Future-proofing and validating development strategies. The IPTS Report 59 at http://www.jrc.es/ home/report/english/articles/vol59/EDIIE596.htm

Gertler, M. S., \& Wolfe, D. A. (2004). Local social knowledge management: Community actors, institutions and multilevel governance in regional foresight exercises. Futures, 36(I), 45-66.

Godet, M. (1986). Introduction to la prospective. Seven key ideas and one scenario method. Futures, I8(2), 134-157. 
Godet, M. (1994). From Anticipation to Action: A Handbook of Strategic Prospective. Paris: United Nations Educational.

Godet, M. (200I). Creating futures. Scenario planning as a strategic management tool. London: Economica.

Gómez-Limón, J. A., Gómez-Ramos, A., \& Sánchez-Fernández, G. (2009). Foresight analysis of agricultural sector at regional level. Futures, $4 I(5), 313-324$.

Halseth, G., Markey, S., \& Bruce, D. (Ed.). (2010). The Next Rural Economies:

Constructing Rural Place in a Global Economy. Wallingford: CAB International.

High, C., \& Nemes, G. (2007). Social learning in Leader: exogenous, endogenous and hybrid evaluation in rural development. Sociologia Ruralis, 47(2), 103-119.

IFAD (2010). Rural Poverty Report 20II. New realities, new challenges: new opportunities for tomorrow's generation. Retrieved from http://www.ifad.org/rpr2oII/

Irwin, E. G., Isserman, A. M., Kilkenny, M., \& Partridge, M. D. (2010). A Century of Research on Rural Development and Regional Issues. American Journal of Agricultural Economics, 92(2), 522-553.

Kay, C. (2009). Development strategies and rural development: exploring synergies, eradicating poverty. Journal of Peasant Studies, 36(I), I03-137.

Kelly, R. (2004). Futures thinking to achieve sustainable development at local level in Ireland. Foresight, 6(2), 80-90.

LEADER European Observatory (1999). Assessing the added value of the LEADER approach: "Rural Innovation". Dossier 4 (LEADER European Observatory Brussels).

Marsden, T. (1995). Beyond agriculture? Regulating the new rural spaces. Journal of Rural Studies, II(3), 285-296.

OECD (2006). The New Rural Paradigm: Policies and Governance. Paris: OECD

Pérez-Correa, E., \& Sumpsi, J. M. (2002). Políticas, instrumentos y experiencias de desarrollo rural en América Latina y Europa (Ministerio de Agricultura, Pesca y Alimentación, Madrid).

Pike, A., Rodríguez-Pose, A., \& Tommaney, J. (2006). Local and Regional Development. Abingdon: Routledge.

Ray, C. (1997). Towards a theory of the dialectic of local rural development within the European Union. Sociologia Ruralis, 37(3), 345-362.

Reutter, W. (2006). England's Regions 2030. The EFMN Foresight Brief 89. European Foresight Monitoring Network, Brussels.

Saraceno, E. (1994). Recent trends in rural development and their conceptualization. Journal of Rural Studies, Io(4), 32I-330. 
Schejtman, A., \& Berdegué, J. (2004). Desarrollo rural territorial. Santiago de Chile: RIMISP.

Sepúlveda, S., Rodríguez, A., \& Portilla, M. (2003). El enfoque territorial del desarrollo rural. San José de Costa Rica: Instituto Interamericano de Cooperación para la Agricultura.

Shortall, S. (2008). Are rural development programmes socially inclusive? Social inclusion, civic engagement, participation, and social capital: exploring the differences. Journal of Rural Studies, 24, 450-457.

Shucksmith, M. (2010). Disintegrated rural development? Neo-endogenous rural development, planning and place-shaping in diffused power contexts. Sociologia Ruralis, 50, I-I4.

Tovey, H. (2008). Rural sustainable development in the knowledge society era. Sociologia Ruralis, 48, I85-199.

Van der Ploeg, J. D., \& Long, A. (1994). Born from within: Practice and perspectives of endogenous rural development. Assen: Van Gorcum.

Van der Ploeg, J. D., Renting, H., Brunori, G., Knickel, K., Mannion, J, Marsden, T... Ventura, F. (2000). Rural Development: From Practices and Policies towards Theory. Sociologia Ruralis, $40(4)$, 39I-408.

World Bank (2008a). Development Economics through the decades. A Critical Look at 30 Years of the World Development Report. Washington DC: World Bank. 